\title{
High Antioxidant and Phenolic Contents Related to Antibacterial Activity against Gastrointestinal Pathogenic Bacteria of Some Thai Medicinal Plants
}

\author{
Parichat Phalanisong ${ }^{1,2}$, Kanit Vichitphan ${ }^{2,3 *}$, Jaehong Han ${ }^{4}$, Sukanda Vichitphan ${ }^{2,3}$
}

\section{Parichat Phalanisong ${ }^{1,2}$, Kanit Vichitphan ${ }^{2,3^{*}}$, Jaehong $\mathrm{Han}^{4}$, Sukanda Vichitphan ${ }^{2,3}$}

\section{'Graduate School, Khon Kaen Uni- versity, Khon Kaen, THAILAND. ${ }^{2}$ Department of Biotechnology, Faculty of Technology, Khon Kaen University, Khon Kaen, THAILAND. \\ ${ }^{3}$ Fermentation Research Center for Value Added Agricultural Products (FerVAAP), Khon Kaen University, Khon Kaen, THAILAND. \\ ${ }^{4}$ Department of Integrative Plant Science, Chung-Ang University, Anseong, KOREA. \\ Correspondence \\ Kanit Vichitphan}

Department of Biotechnology, Faculty of Technology, Khon Kaen University, Khon Kaen, THAILAND.

Phone No: +66 868522929

E mail Id: kanvic@kku.ac.th

History

- Submission Date: 30-10-2017

- Review completed: 20-11-2017;

- Accepted Date: 19-12-2017

DOI : 10.5530/pj.2018.2.58

Article Available online

http://www.phcogj.com/v10/i2

\section{Copyright}

(c) 2018 Phcog.Net. This is an openaccess article distributed under the terms of the Creative Commons Attribution 4.0 International license.

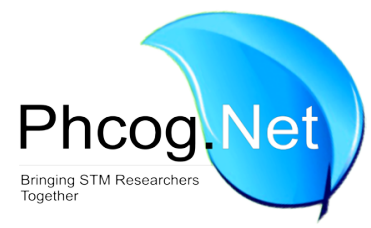

\begin{abstract}
Objective: Thai medicinal plants were used as the traditional medicines and as part of everyday plants diet. Plants contain a mixture of phytochemical and exhibit a lot of functional food and medicinal properties. This project aims to investigate the potential of selected Thai medicinal plants according to the properties of their antioxidant and antibacterial activities. Methods: The eighteen plants were extracted using maceration method with 95\% ethanol. The antioxidant activity was evaluated by DPPH and FRAP assay. The total phenolic content was evaluated by Folin-Ciocalteu phenol reagent. The antibacterial activity was evaluated by agar disc diffusion method. The extract which exhibited high antioxidant and antibacterial activity was selected to observe morphological changes by the scanning electron microscope (SEM). Results: The extract of Caesalpinia sappan showed the highest activities on both antioxidant assayed by FRAP method and total phenolic contents, however, exhibited high antioxidant assayed by DPPH compared to Bauhinia strychnifolia extract. Moreover, the extract of $C$. sappan showed the excellent antibacterial activities against six pathogenic bacteria in Gastro-intestinal tract. The morphological change by SEM was selected for further investigation antibacterial activities of $C$. sappan extract. The results showed that the inhibitory effect to those bacterial strains could be caused by the disruption of the cell membrane and decrease biofilm formation after treatment with the extract. Conclusion: The ethanol extract of $C$. sappan exhibited strong antioxidant and antibacterial activities against the six pathogenic bacteria. This result suggested that $C$. sappan could be applied to use for medicinal purpose and functional products. Key words: Antioxidant activity, Antibacterial activity, Total phenolic content, Caesalpinia sappan, Scanning electron microscope.
\end{abstract}

\section{INTRODUCTION}

Thailand is in a hot and humid climatic zone which supports a high biodiversity of plants. Medicinal plants are concentrated in tropical forests and Thailand's tropical forests support around 12,000 species of vascular plants. ${ }^{1}$ Many of the Thai plants were used as the traditional medicines to treat various illnesses and eaten as the part of everyday meal. Plants contain a mixture of essential, non-essential nutrients and phytochemicals. Their functions as natural antioxidants help prevent oxidative process and delay aging-associated diseases. Essential nutrients such as amino acids, fatty acids, vitamin and minerals are necessary for tissue repair and body's growth. However, they cannot be synthesized by the human body then human can have received those essential nutrients from plant sources. ${ }^{2,3}$

Phytochemicals are group of compounds that are produced by plants for defending against microorganisms and for repairing tissue damages. There are several phytochemicals such as phenolic acids, flavonoids, carotenoids, alkaloids and anthocyanins that have therapeutic properties. ${ }^{4,5,6}$ In addition, many compounds are responsible for plant flavor and aromas. ${ }^{7}$ Since there are many health benefits of essential nutrients and phytochemicals, several plants have been recognized as quality sources for pharmaceutical products and functional ingredients. and functional ingredients. Gastro-intestinal tract or GI tract is an organ system in the human body and animals. The GI tract is not only responsible for food digestion, absorbs nutrients and expels waste materials but also important for protection against pathogenic microorganisms and toxic substances. ${ }^{8,9}$ Gastroenteritis is inflammation of stomach or intestine and it may be caused by bacteria, virus or parasites. Bacterial infections (e.g. Escherichia coli, Salmonella spp., Shigella spp., Campylobacter spp., Helicobacter pylori, Staphylococcus aureus and Bacillus cereus) dominate a common cause of gastroenteritis in humans. ${ }^{10}$ Their symptoms were included diarrhea, vomiting, nausea, salivation, abdominal pain, weakness and bleeding in GI tract. Synthetic antibiotics have been used for the treat-

Cite this article: Phalanisong P, Vichitphan K, Han J, Vichitphan S. High Antioxidant and Phenolic Contents Related to Antibacterial Activity against Gastrointestinal Pathogenic Bacteria of Some Thai Medicinal Plants. Pharmacog J. 2018;10(2):341-8. 
ment of human gastroenteritis. However, those antibiotics are the leading cause of disturbance of the normal gastrointestinal microflora, allergy reactions and antibiotic resistance of bacteria. For these reasons, plants including bioactive compounds and their properties have been investigated to select the new medicinal plants for antibacterial activity in GI tract. ${ }^{11,12,13}$

Previous studies showed the possibility to use many Thai plants as antioxidants and antibacterial agents. Some Thai plant extracts such as Cassia siamea, Garcinia cowa, Limnophila aromatica, Polygonum odoratum, Dioscorea bulbifera, Syzygium cumini and Zingiber zerumbet which have been reported for their antioxidant activities, and these plants also exhibit antibacterial against some pathogenic bacteria. ${ }^{14,15,16,17}$ However, there are many medicinal Thai plants which are not to be evaluated their antioxidant related to antibacterial activities from GI tract. Due to the above-mentioned facts, this project aims to investigate the potential of Thai plants according to the properties of the plant extracts on their antioxidant and antibacterial activities including their effects on morphological changes of selected pathogenic bacteria in GI tract. This information will be used as guide line for development of medicinal products and functional ingredients for use in novel functional food products.

\section{MATERIALS AND METHODS}

\section{Sample collection}

Eighteen plant samples were selected based on Thai traditional medicine and their health promoting properties Table 1. Five fresh plants belonged to three varieties of Pogonatherum crinitum, Oryza sativa and Belamcanda chinensis were harvested from a cultivated field in Khon Kaen province, northeastern part of Thailand. The fresh plants were cleaned, air-dried and ground in an electrical blender (HR2061/20, Philips) into powder. Another thirteen powder plant samples were purchased from a traditional medicine shop in Chum-Phae district, Khon Kaen, Thailand.

\section{Extraction}

The eighteen plant powders were extracted using maceration method with 95\% (v/v) ethanol (Merck, Germany) in the ratio of 1:10 (w/v) for $24 \mathrm{~h}$ at $30^{\circ} \mathrm{C}$. The ethanolic extracts were filtrated through Whatman No. 1 filter paper (Sigma-Aldrich, USA) and were evaporated to dryness

Table 1 Plant samples including family names, scientific names, common name in Thai, parts used and ethnomedical claims.

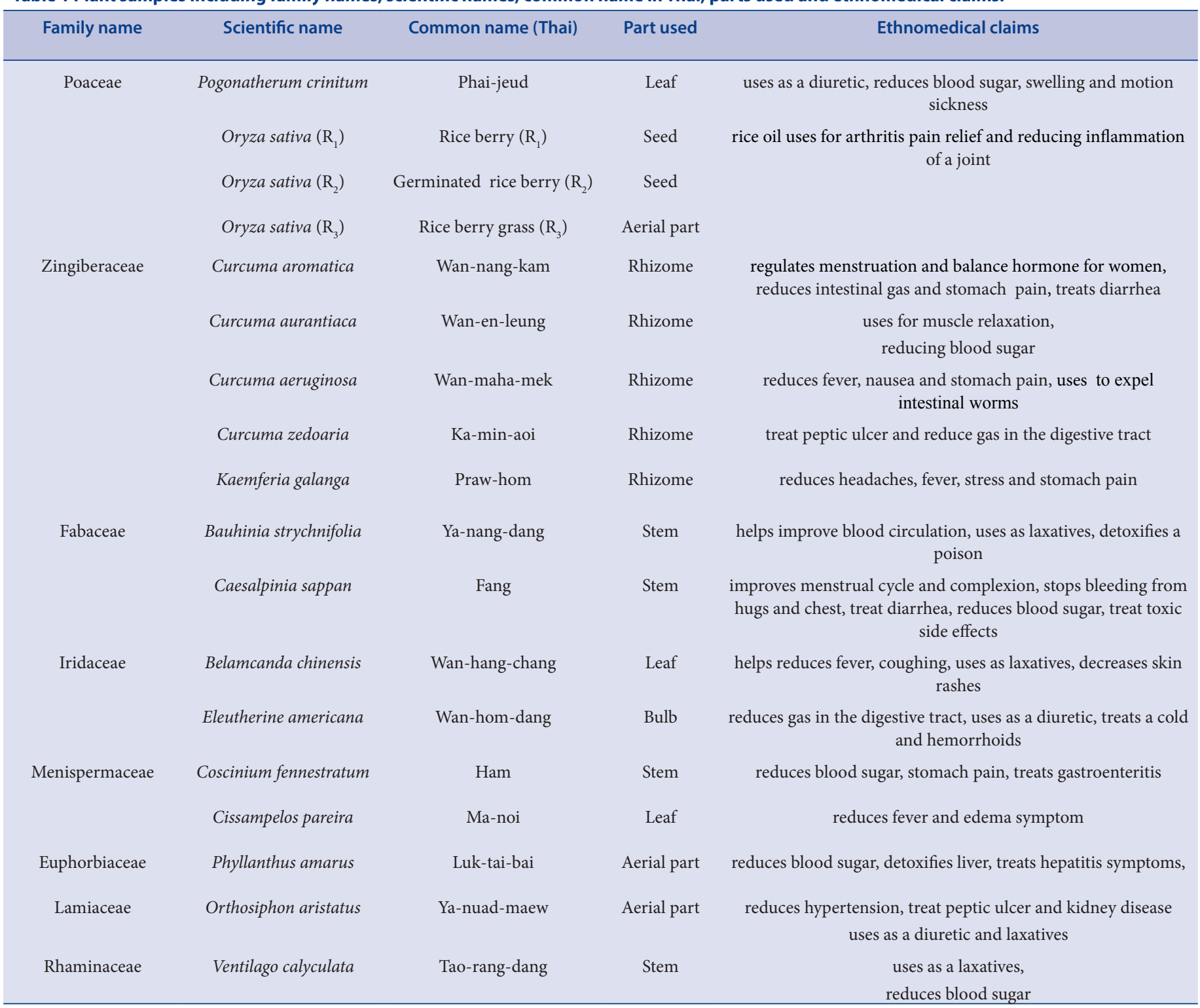


under vacuum using a rotary evaporator. The extracting yields were calculated in percentage based on plant dry weight. The dry or oily extracts were dissolved in dimethyl sulfoxide (DMSO) to get final concentration of $250 \mathrm{mg} / \mathrm{ml}$ before use in all experiments.

\section{Determination of antioxidant activities DPPH radical scavenging activity assay}

The free radical 2,2-Diphenyl-1-picryl-hydrazyl (DPPH) was used to determine the free radical scavenging activities of the extracts. DPPH assay was measured according to a modified method of Dawidowicz et al. ${ }^{18}$ Two milliliter of $0.1 \mathrm{mM} \mathrm{DPPH}$ in methanol was added to $0.1 \mathrm{ml}$ sample solution in $0.9 \mathrm{ml}$ deionized water. The reaction mixtures were kept at $25^{\circ} \mathrm{C}$ in the dark for $30 \mathrm{~min}$. Changes in color were measured at $517 \mathrm{~nm}$ using a UV-2501 PC spectrophotometer (Shimadzu, Japan). The antioxidant activities were reported as mg Trolox equivalent per g dry weight of plant sample. The half maximal inhibitory concentration or $\mathrm{IC}_{50}$ which refers to the extract concentration to inhibit $50 \%$ of the free radicals scavenging activities were determined.

\section{Ferric reducing antioxidant power (FRAP) assay}

The FRAP assay was evaluated according to the modified method of Benzie and Strain. ${ }^{19}$ The FRAP reagent was freshly prepared by mixing $300 \mathrm{mM}$ acetate buffer ( $\mathrm{pH}$ 3.6), $10 \mathrm{mM}$ TPTZ solution in $40 \mathrm{mM} \mathrm{HCl}$ and $20 \mathrm{mM}$ iron (III) chloride solution in proportion of 10:1:1 (v:v:v), respectively. Then, $100 \mu \mathrm{l}$ of the extract was mixed with $3 \mathrm{ml}$ of the FRAP reagent and kept at $25^{\circ} \mathrm{C}$ for $4 \mathrm{~min}$. The change in color was measured at $593 \mathrm{~nm}$ using a UV-2501 PC spectrophotometer (Shimadzu, Japan). The antioxidant activities were recorded as $\mu \mathrm{mol} \mathrm{Fe}{ }^{2+}$ per g dry weight of plant sample.

\section{Determination of total phenolic contents}

Total phenolic contents from the extracts were determined using the modified Folin-Ciocalteu method. ${ }^{20}$ Accordingly, $20 \mu$ of the sample was mixed with $1.58 \mathrm{ml}$ of deionized water and $100 \mu \mathrm{l}$ of Folin-Ciocalteu reagent. After incubation at $25{ }^{\circ} \mathrm{C}$ for $5 \mathrm{~min}, 300 \mu \mathrm{l}$ of $20 \%$ sodium carbonate solution was added to the reaction mixture. Gallic acid was a used as standard and the absorbance of the blue color was measured at $765 \mathrm{~nm}$ using a UV-2501 PC spectrophotometer (Shimadzu, Japan). The results were expressed as $\mathrm{mg}$ Gallic acid equivalent per $\mathrm{g}$ dry weight of sample.

\section{Bacterial culture}

Six varieties of pathogenic bacteria, Bacillus cereus TISTR687, Staphylococcus aureus TISTR1466, Enterococcus faecalis TISTR379, Enterobacter aerogenes TISTR1540, Salmonella typhimurium TISTR292 and Escherichia coli TISTR780 which caused infection of the gastrointestinal tract were obtained from the Thailand Institute of Scientific and Technological Research (TISTR), Bangkok, Thailand. The six bacteria were culture in Tryptic Soy Broth (HiMedia, India) for $18-24 \mathrm{~h}$ at $37^{\circ} \mathrm{C}$.

\section{Determination of antibacterial activities}

The antibacterial activities were determined by using the agar disc diffusion method. ${ }^{21}$ After each pathogenic bacterium was grown to log phase, the culture turbidity was adjusted by comparison with McFarland standard No. 0.5 and then was swabbed on the surface of Muller Hinton agar (MHA) plates. The sterile paper discs with a diameter of $6 \mathrm{~mm}$ were soaked in $30 \mu \mathrm{l}$ of $250 \mathrm{mg} / \mathrm{ml}$ extract solution and were placed on the surface of pre-inoculated testing bacteria plates. The plates were incubated at $37^{\circ} \mathrm{C}$ for $24 \mathrm{~h}$. The antimicrobial activity of each crude extract was evaluated by measuring the diameter of inhibition zone. For each extract three replicates measured, and their average value was recorded.

\section{Preparation of the cells for Scanning Electron Microscopy (SEM)}

The SEM was performed by the modified method of Daduang et al. ${ }^{22}$ Briefly, the cells of the six bacteria which were nearly or close to the inhibition zones on plates after treated with plant extracts for $24 \mathrm{~h}$ were taken and investigated the morphological changes by SEM. The cells were harvested and fixed by $2.5 \%(\mathrm{v} / \mathrm{v})$ glutaraldehyde in $0.1 \mathrm{M}$ sodium phosphate buffer $(\mathrm{pH} 7.2)$. All tested cells were rinsed with $0.1 \mathrm{M}$ sodium phosphate buffer ( $\mathrm{pH} 7.2$ ) and post-fixed with $1 \%$ osmium tetroxide $\left(\mathrm{OsO}_{4}\right)$ in the same buffer solution. After rinsed by $0.1 \mathrm{M}$ sodium phosphate buffer ( $\mathrm{pH} 7.2)$, the cells were dehydrated with a series of 20, 40, 60,80 and $100 \%$ (v/v) ethanol, respectively. Finally, all cells were coated with gold for getting the conductivity. The coating cells were examined using scanning electron microscope (JEOL: JSM-6460 LV, USA).

\section{Statistical analysis}

For our statistical analysis three replicates for each experiment were evaluated and the results were expressed as mean \pm SD. Correlation between antioxidant activities and total phenolic contents were analyzed using SPSS software version 19 (IBM), and P-value less than 0.05 was considered to be significant

\section{RESULTS}

\section{Antioxidant activities and total phenolic contents}

Antioxidant activities and total phenolic contents of the eighteen plant extracts were shown in Table 2 . The results indicated that the total phenolic contents of the eighteen extracts exhibited a wide range of $0.27 \pm 0.01$ to $52.56 \pm 0.73 \mathrm{mg} \mathrm{GAE} / \mathrm{g}$ dry weight. In case of antioxidant activities, the values of FRAP assay varied from $1.38 \pm 0.03$ to $354.95 \pm 4.96 \mu \mathrm{mol}$ $\mathrm{Fe}^{2+} / \mathrm{g}$ dried weight while the DPPH free-radical scavenging activities of the extracts expressed as mg of Trolox equivalent were $0.64 \pm 0.02$ to $54.28 \pm 0.21 \mathrm{mg}$ TE/g dry weight. The $\mathrm{IC}_{50}$ of extracts were in range 0.13 to $15.05 \mathrm{mg} / \mathrm{ml}$ by DPPH assay. The correlation between total phenolic contents and antioxidant activities of the eighteen plant extracts were statistically analyzed by SPSS 19 . The $r$ values of DPPH and FRAP assay were 0.84 and 0.97 , respectively (Figure 1 ). The results of both antioxidant methods expressed well with positive linear correlation with total phenolic contents.

The extract of C. sappan exhibited the highest antioxidant activity (354.95 $\pm 4.96 \mu \mathrm{mol} \mathrm{Fe}{ }^{2+} / \mathrm{g}$ dried weight) and total phenolic contents (52.56 $\pm 0.73 \mathrm{mg} \mathrm{GAE} / \mathrm{g}$ dry weight) by FRAP and the Folin-Ciocalteu
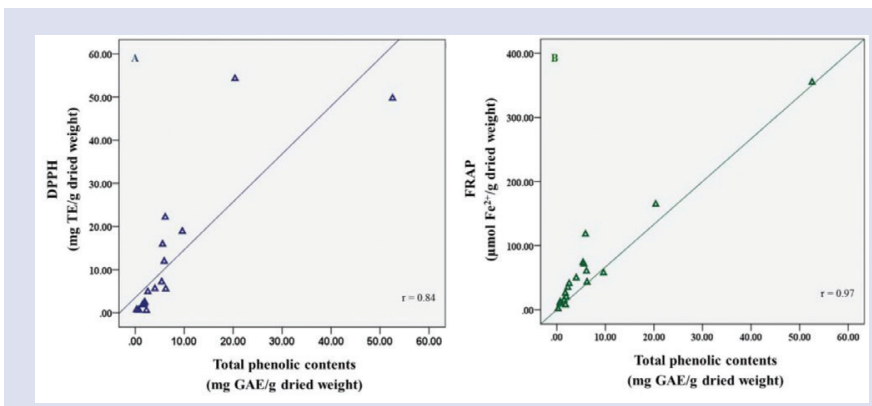

Figure 1: Relationship between total phenolic contents and antioxidant activities of 18 plant extracts analyzed by DPPH assay (A) and FRAP assay (B). 
Table 2 Total phenolic contents and antioxidant activity of the eighteen plant extracts

\begin{tabular}{|c|c|c|c|c|}
\hline \multirow[t]{3}{*}{ Plant extract } & \multirow{3}{*}{$\begin{array}{l}\text { Total phenolic contents } \\
\text { (mg GAE/g dry wt) }\end{array}$} & \multicolumn{3}{|c|}{ Antioxidant activities } \\
\hline & & \multicolumn{2}{|c|}{ DPPH radical scavenging activity } & \multirow{2}{*}{$\begin{array}{l}\text { Ferric reducing activity } \\
\text { ( } \mu \mathrm{mol} \mathrm{Fe} 2+/ \mathrm{g} \text { dry wt) }\end{array}$} \\
\hline & & (mg TE/g dry wt) & $I C_{50}(\mathrm{mg} / \mathrm{ml})$ & \\
\hline P. crinitum & $5.39 \pm 0.09$ & $7.16 \pm 0.13$ & 0.49 & $73.60 \pm 1.04$ \\
\hline O. sativa $\left(\mathrm{R}_{1}\right)$ & $0.70 \pm 0.03$ & $0.64 \pm 0.02$ & 3.08 & $12.03 \pm 0.21$ \\
\hline O. sativa $\left(\mathrm{R}_{2}\right)$ & $0.27 \pm 0.01$ & $0.70 \pm 0.04$ & 11.80 & $1.38 \pm 0.03$ \\
\hline O. sativa $\left(\mathrm{R}_{3}\right)$ & $1.80 \pm 0.03$ & $2.05 \pm 0.02$ & 1.89 & $7.40 \pm 0.12$ \\
\hline C. aromatica & $9.61 \pm 0.22$ & $18.86 \pm 0.08$ & 0.88 & $57.69 \pm 2.95$ \\
\hline C. aurantiaca & $6.11 \pm 0.16$ & $22.16 \pm 0.53$ & 1.18 & $60.17 \pm 2.45$ \\
\hline C. aeruginosa & $1.94 \pm 0.04$ & $2.45 \pm 0.05$ & 2.67 & $19.78 \pm 0.18$ \\
\hline C. zedoaria & $6.22 \pm 0.17$ & $5.54 \pm 0.09$ & 1.83 & $43.14 \pm 0.32$ \\
\hline K. galangal & $0.68 \pm 0.02$ & $0.64 \pm 0.01$ & 15.05 & $9.61 \pm 0.92$ \\
\hline B. strychnifolia & $20.37 \pm 0.40$ & $54.28 \pm 0.21$ & 0.13 & $164.53 \pm 0.20$ \\
\hline C. sappan & $52.56 \pm 0.73$ & $49.74 \pm 0.99$ & 0.14 & $354.95 \pm 4.96$ \\
\hline B. chinensis & $1.76 \pm 0.03$ & $2.22 \pm 0.02$ & 3.05 & $25.84 \pm 1.43$ \\
\hline E. americana & $2.55 \pm 0.05$ & $4.88 \pm 0.11$ & 0.63 & $40.84 \pm 0.25$ \\
\hline C. fennestratum & $2.28 \pm 0.10$ & $0.52 \pm 0.01$ & 7.21 & $34.76 \pm 0.90$ \\
\hline C. pareira & $1.47 \pm 0.04$ & $1.82 \pm 0.06$ & 2.42 & $15.30 \pm 0.55$ \\
\hline P. amarus & $5.90 \pm 0.20$ & $11.94 \pm 0.22$ & 0.22 & $117.95 \pm 0.44$ \\
\hline O. aristatus & $5.57 \pm 0.11$ & $15.90 \pm 0.44$ & 0.37 & $71.34 \pm 0.62$ \\
\hline V. calycalata & $4.00 \pm 0.02$ & $5.60 \pm 0.13$ & 0.74 & $49.77 \pm 0.90$ \\
\hline
\end{tabular}

${ }^{*}$ Note; the results are expressed as mean $\pm S D(n=3)$

assays. The extract of $B$. strychnifolia exhibited the highest capacities to neutralize DPPH free-radicals $(54.28 \pm 0.21 \mathrm{mg}$ TE/g dry weight) with slightly higher than extract of C. sappan $(49.74 \pm 0.99 \mathrm{mg}$ TE/g dry weight). The $\mathrm{IC}_{50}$ of $B$. strychnifolia extract $(0.13 \mathrm{mg} / \mathrm{ml})$ slightly differed from C. sappan extract $(0.14 \mathrm{mg} / \mathrm{ml})$ supporting the high antioxidant activity of both extract of C. sappan and B. strychnifolia by DPPH assay.

\section{Antibacterial activity}

The eighteen crude plant extracts ( $250 \mathrm{mg} / \mathrm{ml}$ in DMSO) were evaluated for their antibacterial activities against the six pathogenic bacteria which were separated into three G-positive bacteria (Bacillus cereus TISTR687, Staphylococcus aureus TISTR1466 and Enterococcus faecalis TISTR379) and three G-negative bacteria (Enterobacter aerogenes TISTR1540, Salmonella typhimurium TISTR292 and Escherichia coli TISTR780) by agar disc diffusion method. The results showed in Table 3.

All eighteen plant extracts could inhibit B. cereus (G-positive bacteria) and the inhibition zone was ranging from $6.50 \pm 0.00$ to $26.83 \pm 0.76 \mathrm{~mm}$. The eleven plant extracts which were C. aromatica, C. aurantiaca, C. aeruginosa, C. zedoaria, K. galanga, B. strychnifolia, C. sappan, E. americana, C. fennestratum, $P$. amarus and $V$. calycalata could inhibit $S$. aureus and E. faecalis (G-positive bacteria) with the inhibition zone ranging from $6.67 \pm 0.29$ to $27.50 \pm 0.87 \mathrm{~mm}$. However, the seventeen plant extracts could not inhibit the growth of those three G-negative bacteria. Only the C. sappan extract from the heart wood showed remarkable broad-spectrum inhibition activity against both G-positive and G-negative bacteria and the zone of inhibition was in range $26.83 \pm 0.76$ to $27.50 \pm 0.87 \mathrm{~mm}$ and $10.00 \pm 0$ to $14.83 \pm 0.76 \mathrm{~mm}$, respectively Table 3 and Figure 2. The $100 \%$ DMSO was performed as negative control in all experiments and all shown no inhibition.

\section{Scanning Electron Microscopy (SEM)}

The morphological changes of G- positive and G-negative bacterial cells after treated with the extract of $C$. sappan were observed under the SEM and the results showed in Figure 3 and Figure 4. Two G-positive bacterial cells of E. faecalis TISTR379 and S. aureus TISTR1466 treated with C. sappan were swollen and some bacterial cells were broken which indicated by the red arrows (Figure 3: A2 and B2) when compared with the untreated cells (Figure 3: A1 and B1). A different result was found in the cells of $B$. cereus TISTR687. The treated cells of $B$. cereus TISTR687 showed different size and some area on the cell surface was cracked (Figure 3: C2), while untreated cells exhibited a normal shape (Figure 3: C1). The G-negative bacterial cells after treated with C. sappan extract were shown in the Figure 4. The cells of S. typhimurium TISTR292 have shorten and deformed (Figure 4: D2) when compared with the untreated group (Figure 4: D1). In addition, small pores appeared on the cell surfaces of E. aerogenes TISTR1540 (Figure 4: E2). However, the size of $E$. aerogenes TISTR1540 cells treated by the extract of C. sappan is like the normal cells (Figure 4: E1). The size of cells of E. coli TISTR780 after treated with the extract increased and deformed (Figure 4: F2) compared to normal cells (Figure 4: F1).

\section{DISCUSSION}

The Thai medicinal plants in this study were selected based on their use in traditional medicine for health promotion. Ethnomedical claims have advantages for selecting plant samples based on their continuous use by humans. ${ }^{23}$ So, the bioactive compounds contained in these plants can be safer than the plants with no ethnomedical records. The extracts of selected plants were evaluated according to their antioxidant activity, total phenolic contents and antibacterial activity. The investigation for 


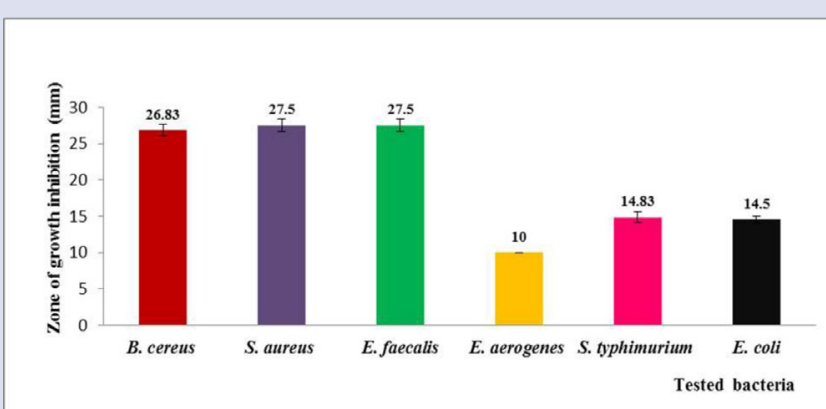

Figure 2: Diameter of inhibition zone of the ethanol extract of Caesalpinia sappan on growth of the six pathogenic bacteria.
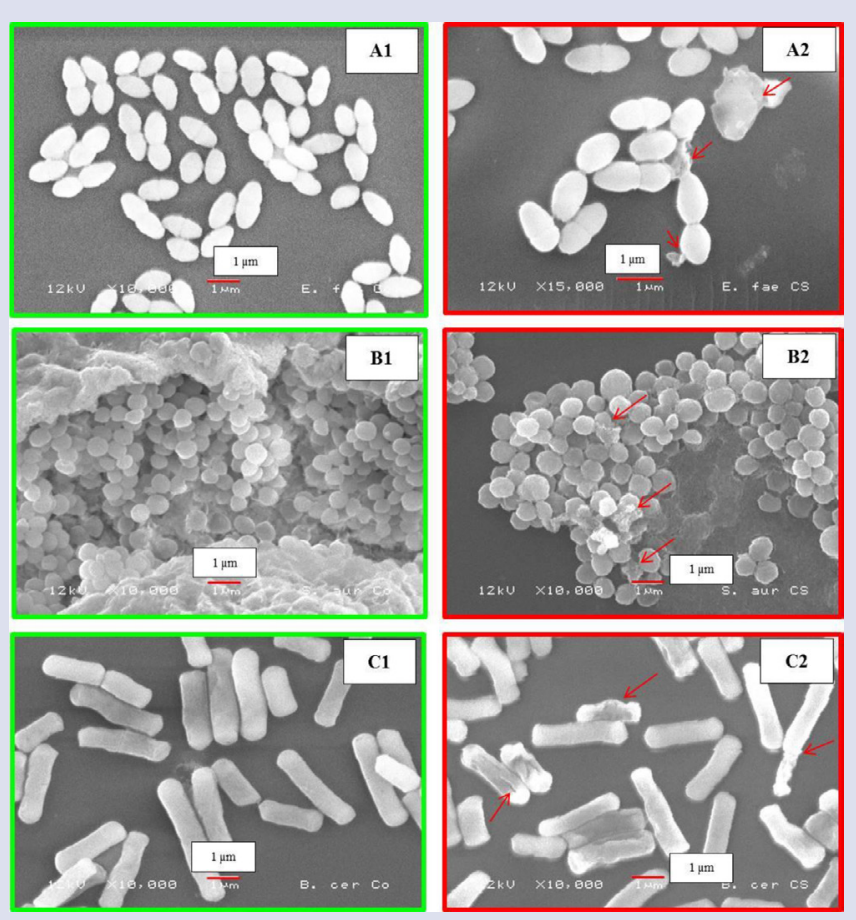

Figure 3: Scanning electron micrographs of Gram-positive cells: E. faecalis TISTR379 (A2), S. aureus TISTR1466 (B2) and B. cereus TISTR687 (C2) treated with the $95 \%$ ethanol extract of Caesalpinia sappan at $37^{\circ} \mathrm{C}$ for 24 hours and compared to the untreated cells: E. faecalis TISTR379 (A1), S. aureus TISTR1466 (B1) and B. cereus TISTR687 (C1).

their properties could give us the information on a new potential source for health promotion.

Antioxidant activities and total phenolic contents were evaluated in ethanol extract of eighteen plant sample by using two in vitro methods. The FRAP assay was used to evaluate the capacity of extracts to reduce ferric ions $\left(\mathrm{Fe}^{3+}\right)$ to ferrous ion $\left(\mathrm{Fe}^{2+}\right)$. This method is rapid for antioxidant determination. DPPH was evaluated only the capacity of extracts to neutralize free radicals by transferring electron or hydrogen atom to $\mathrm{DPPH} .{ }^{24,25} \mathrm{DPPH}$ assay is the most frequently used for in vitro antioxidant determination for plant sample because this method is simple and inexpensive. ${ }^{26}$ Among all extracts, the extract Caesalpinia sappan exhibited the highest antioxidant activity measured by FRAP assay ( $354.95 \pm 4.96 \mu \mathrm{mol} \mathrm{Fe} \mathrm{F}^{2+} / \mathrm{g}$ dried weight), while extracts of B. strychnifolia and C. sappan exhibited the high capacities to neutralize DPPH free-radicals $(54.28 \pm 0.21$ and $49.74 \pm 0.99 \mathrm{mg} \mathrm{TE} / \mathrm{g}$
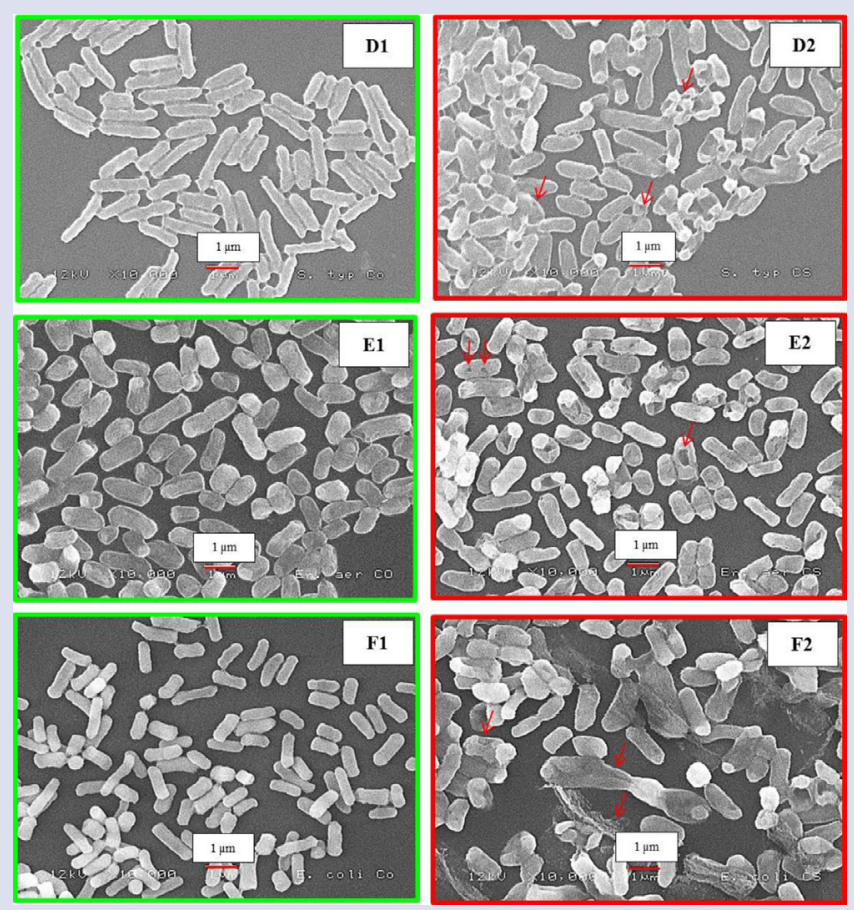

Figure 4: Scanning electron micrographs of Gram-negative cell: S. typhimurium TISTR292 (D2), E. aerogenes TISTR1540 (E2) and E. coli TISTR780 (F2) treated with the 95\% ethanol extract of Caesalpinia sappan at $37^{\circ} \mathrm{C}$ for 24 hours and compared to the untreated group: S. typhimurium TISTR292 (D1), E. aerogenes TISTR1540 (E1) and E. coli TISTR780 (F1)

dry weight, respectively) with $\mathrm{IC}_{50}$ values of 0.13 and $0.14 \mathrm{mg} / \mathrm{ml}$, respectively. Considering both extracts of C. sappan and B. strychnifolia also presented capacity to use as antioxidant sources. Correlation between total phenolic contents and antioxidant activities of eighteen plant extracts were further studied using SPSS 19 software. A positive correlation between total phenolic contents and antioxidant activities in all extracts exhibited the significant linear relationship with $r$ values of 0.84 for DPPH assay and 0.97 for FRAP assay. This result indicated that phenolic compounds probably were the dominant antioxidant components in the plant samples.

The results of antibacterial activity indicated that the ethanol extract of $C$. sappan from heart wood showed the wide range of antibacterial activities on the growth of both G-positive bacteria (Bacillus cereus) TISTR687, Staphylococcus aureus TISTR1466 and Enterococcus faecalis TISTR379) and G-negative bacteria (Enterobacter aerogenes TISTR1540, Salmonella typhimurium TISTR292 and Escherichia coli TISTR780). The maximum inhibiting activity of the ethanol extract of C. sappan for several microorganisms such as Pseudomonas aeruginosa, Staphylococcus aureus, Salmonella typhi, Enterobacter aerogens, Candida albicans and Escherichia coli have been reported. ${ }^{27}$ Brazilin (the main bioactive homoisoflavone) and Juglone (5-hydroxy-1, 4-naphthoquinone) were reported as bioactive compounds which presented an antimicrobial property. ${ }^{28,29}$ This information supports our results antimicrobial activity of ethanol extract of C. sappan to six pathogenic bacteria in GI tract.

Cells around inhibition zone of the six gastrointestinal pathogenic bacteria after treated by ethanol extract of Caesalpinia sappan were further observed using SEM. Considering G-positive bacterial cells, Staphylococcus aureus TISTR1466 and Enterococcus faecalis TISTR379 were swollen and broken. However, different result was found in the rod-shaped cells 
Table 3: Antibacterial activities of plant extracts against the six pathogenic bacteria

\begin{tabular}{|c|c|c|c|c|c|c|}
\hline \multirow[t]{2}{*}{ Plant extract } & \multicolumn{6}{|c|}{ Zone of inhibition (mm) } \\
\hline & B. cereus & S. aureus & E. faecalis & E. aerogenes & S. typhimurium & E. coli \\
\hline P. crinitum & $9.00 \pm 0.50$ & $7.83 \pm 0.04$ & ni & ni & ni & ni \\
\hline O. sativa $\left(R_{1}\right)$ & $6.50 \pm 0.00$ & ni & ni & ni & ni & ni \\
\hline O. sativa $\left(R_{3}\right)$ & $6.50 \pm 0.00$ & ni & ni & ni & ni & ni \\
\hline C. aromatica & $10.83 \pm 0.29$ & $8.17 \pm 0.29$ & $7.00 \pm 0.00$ & ni & ni & ni \\
\hline C. aurantiaca & $10.33 \pm 0.58$ & $7.17 \pm 0.29$ & $7.17 \pm 0.29$ & ni & ni & ni \\
\hline K. galanga & $7.00 \pm 0.00$ & $7.67 \pm 0.29$ & $7.67 \pm 0.29$ & $\mathrm{ni}$ & ni & ni \\
\hline B. strychnifolia & $13.00 \pm 0.50$ & $12.67 \pm 0.29$ & $11.17 \pm 0.29$ & ni & ni & ni \\
\hline C. sappan & $26.83 \pm 0.76$ & $27.50 \pm 0.87$ & $27.50 \pm 0.87$ & $10.00 \pm 0.00$ & $14.83 \pm 0.76$ & $14.50 \pm 0.50$ \\
\hline B. chinensis & $7.50 \pm 0.50$ & ni & $\mathrm{ni}$ & ni & ni & ni \\
\hline E. americana & $17.50 \pm 0.50$ & $16.00 \pm 0.50$ & $16.00 \pm 0.50$ & ni & ni & ni \\
\hline C. fennestratum & $19.50 \pm 0.50$ & $22.33 \pm 1.15$ & $11.33 \pm 0.58$ & ni & ni & ni \\
\hline $\begin{array}{l}\text { Negative control } \\
\text { (DMSO) }\end{array}$ & $\mathrm{ni}$ & $\mathrm{ni}$ & $\mathrm{ni}$ & $\mathrm{ni}$ & $\mathrm{ni}$ & ni \\
\hline
\end{tabular}

${ }^{*}$ Note; the results are expressed as mean $\pm \mathrm{SD}$; the concentration of tested extracts is $250 \mathrm{mg} / \mathrm{ml}(30 \mu \mathrm{l} / \mathrm{disc})$; the negative control is $100 \% \mathrm{DMSO}(30 \mu \mathrm{l} / \mathrm{disc})$; $\mathrm{ni}=\mathrm{no}$ inhibition

of Bacillus cereus TISTR687 with cell surface was cracked before damaged. Kamonwannasit et al. ${ }^{30}$ have demonstrated that the extract of the Aquilaria crassna leaf could inhibit the growth of Staphylococcus epidermidis. Scanning electron micrographs also showed the swollen cells after treated by the extract of A. crassna. Moreover, biofilm formation of $S$. epidermidis was inhibited by the plant extract. A similar effect has been found in this study which showed that $S$. aureus TISTR1466 exhibited disposing of cells compared to dense cells of untreated cells. It is possible that the biofilm produced by $S$. aureus TISTR1466 was reduced after treatment with the extract of $C$. sappan. The biofilms contribute to most of infectious diseases caused by bacterial and fungal pathogens. ${ }^{31}$ The results from SEM micrograph indicate that the extract of C. sappan, which contains the high concentration of phenolic contents, able to inhibit the growth of bacteria and decrease in virulent infection of Staphylococcus aureus. In case of G-negative bacteria, cells of Enterobacter aerogenes TISTR1540 and Salmonella typhimurium TISTR292 after treated with the extract have shrunk and deformed, while cells of Escherichia coli TISTR780 have longer rod and increasing size before broken. Cell surface damage of all tested bacteria was appeared after treatment with the extract and this cause might lead to induced leakage of cells. Previous studies have reported that some phenolic compounds derived from plants had effect on cytoplasmic membrane of bacterial cells and lost membrane integrity. ${ }^{32,33,34}$ These results could be concluded that the C. sappan extract has the capacity to interrupt biofilm formation and cell membrane formation, thus can be used as an antimicrobial agent.

\section{CONCLUSION}

The ethanol extract of Caesalpinia sappan exhibited high antioxidant and phenolic contents related to antibacterial activities against the pathogenic bacteria in GI tract. These results will pave the way to use C. sappan as antibacterial in GI tract and beneficial for ingredient of health products. 


\section{ACKNOWLEDGEMENT}

This research was financially supported by Graduate School, Khon Kaen University and Research Center for Value Added Agricultural Products (FerVAAP).

\section{CONFLICT OF INTEREST}

The authors declare no conflict of interest.

\section{ABBREVIATIONS USED}

SEM: Scanning Electron Microscope; DMSO: Dimethyl sulfoxide; DPPH: 2,2-Diphenyl-1-picryl-hydrazyl; FRAP: Ferric Reducing Antioxidant Power; TPTZ: 2,4,6-tripyridyl-s-triazine; MHA: Muller Hinton Agar; GI tract: Gastro-intestinal tract; IC $_{50}$ : The half maximal inhibitory concentration; TISTR: Thailand Institute of Scientific and Technological Research; G-positive: Gram-positive; G-negative: Gram-negative; GAE: Gallic acid equivalent; TE: Trolox equivalent.

\section{REFERENCES}

1. Baimai V. Biodiversity of Thailand. The Journal of the Royal Institute of Thailand 2010;2: 107-9

2. Mann J, Truswell AS. Essential of human nutrition. $2^{\text {nd }}$ ed. New York: Oxford University; 2002;p1-21.

3. Roth RA. Nutrition and Diet therapy. 10 ${ }^{\text {th }}$ ed. Indiana: Purdue University; 2011

4. Tiwari AK, Rao JM. Diabetes mellitus and multiple therapeutic approaches of phytochemicals: present status and prospects. Current Science. 2002;83(1):30-8.

5. Mishra S, Aeri V, Gaur PK, Jachak SM. Phytochemical, therapeutic, and ethnopharmacological overview for a traditionally important herb: Boerhavia diffusa Linn. Biomed Res Int. 2014;1-19.

6. Tariq A, Mussarat S, Adnan M. Review on ethnomedicinal, phytochemical and pharmacological evidence of Himalayan anticancer plants. J Ethnopharmacol. 2015;164(22):96-119.

7. Saxena M, Saxena J, Nema R, Singh D, Gupta A. Phytochemistry of medicinal plants. J Pharmacogn Phytochem. 2013;1(6):168-82.

8. Stipanuk MH, Caudill MA. Biochemical, physiological, and molecular aspects of human nutrition. $3^{\text {rd }}$ ed. USA: Saunders. 2012. p. 123-30

9. Jandhyala SM, Talukdar R, Subramanyam C, Vuyyuru H, Sasikala M, Reddy DN Role of the normal gut microbiota. World J Gastroenterol. 2015;21(29):8787-803.

10. Conlon CP. Gastrointestinal tract: bacterial infections. Encyclopedia of Life Science. New York: John Wiley and Son, Ltd.; 2001.

11. Palombo EA. Phytochemicals from traditional medicinal plants used in the treatment of diarrhea: modes of action and effects on intestinal function. Phytother Res. 2006;20(9):717-24.

12. Cardona F, Andres-Lacueva C, Tulipani S, Tinahones FJ, Queipo-Ortuno MI. Benefit of polyphenols on gut microbiota and implications in human health. J Nutr Biochem. 2013;24(8):1415-22.

13. Safavi M, Shams-Ardakani M, Foroumadi A. Medicinal plants in the treatment of Helicobacter pylori infections. Pharm Biol. 2015;53(7):939-60.

14. Nanasombat S, Teckchuen N. Antimicrobial, antioxidant and anticancer activities of Thai local vegetables. J. Med. Plants Res. 2009;3(5):443-49.

15. Chunthorng-Orn J, Panthong S, Itharat A. Antimicrobial, antioxidant activities and total phenolic content of Thai medicinal plants used to treat HIV patients. $J$ Med Assoc Thai. 2012;1:S154-8.

16. Mueller $\mathrm{M}$, Janngeon $\mathrm{K}$, Puttipan $\mathrm{R}$, Unger FM, Viernstein $\mathrm{H}$, Okonogi S. Antiinflammatory, antibacterial, and antioxidant activities of Thai medicinal plants. Int J Pharm Sci Res. 2015;7:123-8.

17. Thummajitsakul S, KaewsriW, Deetae P. Analysis of intraspecific genetic variation, antioxidant and antibacterial activities of Zingiber zerumbet. International Food Research Journal. 2016:23(4):1552-7.

18. Dawidowicz AL, Wianowska D, Olszowy M. On practical problems in estimation of antioxidant activity of compounds by DPPH method (problems in estimation of antioxidant activity). Food Chem. 2012;131(3):1037-43.

19. Benzie IF, Strain JJ. Ferric reducing/antioxidant power assay: direct measure of total antioxidant activity of biological fluids and modified version for simultaneous measurement of total antioxidant power and ascorbic acid concentration. Methods Enzymol. 1999;299:15-27.

20. Singleton VL, Orthofer R, Lamuela-Raventos RM. Analysis of total phenols and other oxidation substrates and antioxidants by means of folin-ciocalteu reagent. Methods Enzymol. 1999;299:152-78.

21. CLSI: Clinical and Laboratory Standard Institute. Performance standard for antimicrobial susceptibility testing; sixteenth information supplement. Wayne, USA:PA19087. 2006

22. Daduang J, Vichitphan S, Daduang S, Hongsprabhas P, Boonsiri P. High phenolics and antioxidants of some tropical vegetables related to antibacterial and anticancer activities. Afr J Pharm Pharmacol. 2011;5(5):608-15.

23. Jaganathan RM, Mahendra L, Mahendra J, Kumanan V, Kathaperumal K. Ethnomedical herbs and various approaches in development of new drugs. World $J$ Pharm Res. 2016;5:869-76.

24. Molyneux P. The use of the stable free radical diphenyl picrylhydrazyl (DPPH) for estimating antioxidant activity. Songklanakarin J. Sci. Technol. 2004;26(2):211-19.

25. Alam MN, Bristi NJ, Rafiquzzaman M. Review on in vivo and in vitro methods evaluation of antioxidant activity. Saudi Pharm J. 2013;21(2):143-52.

26. Krishnaiah D, Sarbatly R, Nithyanandam R. A review of the antioxidant potential of medicinal plant species. Food and Bioproducts Processing. 2011;89(3):217-33.

27. Nirmal NP, Rajput MS, Prasad RG, Ahmad M. Brazilin from Caesalpinia sappan heartwood and its pharmacological activities: A review. Asian Pac J Trop Med. 2015;8(6):421-30.

28. Lim MY, Jeon JH, Jeong EY, Lee CH, Lee HS. Antimicrobial activity of 5-hydroxy-1, 4-naphthoquinone isolated from Caesalpinia sappan toward intestinal bacteria. Food Chem. 2007;100(3):1254-8.

29. Batubara I, Mitsunaga T, Ohashi H. Brazilin from Caesalpinia sappan wood as an anti-acne agent. J Wood Sci. 2010;56(1):77-81.

30. Kamonwannasit S, Nantapong N, Kumkrai P, Luecha $P$, Kupittayanant S, Chudapongse N. Antibacterial activity of Aquilaria crassna leaf extract against Staphylococcus epidermidis by disruption of cell wall. Ann Clin Microbiol Antimicrob. 2013;12(1):20.

31. Rumbaugh KP, Ahmad I. Antibiofilm agents: from diagnosis to treatment and prevention. USA: Springer. 2014;3-14.

32. Campos FM, Couto JA, Figueiredo AR, Toth IV, Rangel AO, Hogg TA. Cell membrane damage induced by phenolic acids on wine lactic acid bacteria. Int J Food Microbiol. 2009:135(2):144-51.

33. Albano M, Alves FC, Andrade BF, Barbosa LN, Pereira FM, Cunha ML, et al. Antibacterial and anti-staphylococcal enterotoxin activities of phenolic compounds. Innov Food Sci Emerg Technol. 2016;38:83-90

34. Cloutier CA, Vincken JP, Ederen R, Besten HM, Gruppen H. Rapid membrane permeabilization of Listeria monocytogenes and Escherichia coli induced by antibacterial prenylated phenolic compounds from legumes. Food Chem. 2018;240:147-55.

\section{ABOUT AUTHORS}

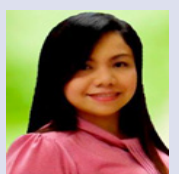

Parichat Phalanisong: obtained her M.S. degree in 2008 from Chiang Mai University, Thailand. Currently, she is Ph.D. candidate in Biotechnology at Department of Biotechnology, Faculty of Technology, Khon Kaen University, Thailand. Her research projects are focus on plant biochemistry, nutraceuticals and functional foods.

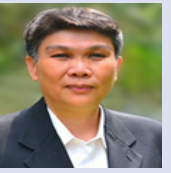

Kanit Vichitphan: obtained his Ph.D. degree in 2001 from Verginia Polytechnic Institute and State University, USA. Currently, he is Assistant Professor and senior lecturer at Department of Biotechnology, Faculty of Technology, Khon Kaen University, Thailand. His research projects are focus on enzyme technology and natural product from plants. 
GRAPHICAL ABSTRACT

Eighteen ethanol extracts of Thai medicinal plants

Folin-Ciocalteu method,

DPPH and FRAP methods

Total phenolic contents and antioxidant activities

Agar disc diffusion method

Inhibitory effect on six pathogenic bacteria in Gl tract

Scanning Electron Microscope (SEM)

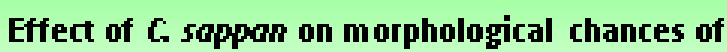
pathogenic bacteria in GI tract
SUMMARY

- $\quad$ Caesalpinia sappan exhibited strong antioxidant and antibacterial activities against some pathogenic bacteria in GI tract.

- Morphological observation by SEM showed that the extract of C. sappan has the capacity to interrupt biofilm formation and cell membrane formation.

- C. sappan could be used as antibacterial agent and ingredient of health products.

Cite this article: Phalanisong P, Vichitphan K, Han J, Vichitphan S. High Antioxidant and Phenolic Contents Related to Antibacterial Activity against Gastrointestinal Pathogenic Bacteria of Some Thai Medicinal Plants. Pharmacog J. 2018;10(2):341-8. 